\title{
Effect of purified $\beta$-glucans derived from Laminaria digitata, Laminaria hyperborea and Saccharomyces cerevisiae on piglet performance, selected bacterial populations, volatile fatty acids and pro-inflammatory cytokines in the gastrointestinal tract of pigs
}

\author{
T. Sweeney, C. B. Collins, P. Reilly, K. M. Pierce, M. Ryan and J. V. O’Doherty* \\ School of Agriculture, Food Science and Veterinary Medicine, College of Life Sciences, University College Dublin, Belfield, \\ Dublin 4, Republic of Ireland \\ (Submitted 11 April 2011 - Final revision received 9 November 2011 - Accepted 10 November 2011 - First published online 7 February 2012)
}

\begin{abstract}
$\beta$-Glucans have been identified as natural biomolecules with immunomodulatory activity. The first objective of the present study was to compare the effects of purified $\beta$-glucans derived from Laminaria digitata, L. hyperborea and Saccharomyces cerevisiae on piglet performance, selected bacterial populations and intestinal volatile fatty acid (VFA) production. The second aim was to compare the gene expression profiles of the markers of pro- and anti-inflammation in both unchallenged and lipopolysaccharide (LPS)-challenged ileal and colonic tissues. $\beta$-Glucans were included at $250 \mathrm{mg} / \mathrm{kg}$ in the diets. The $\beta$-glucans derived from L. hyperborea, L. digitata and $S$. cerevisiae all reduced the Enterobacteriaceae population $(P<0.05)$ without influencing the lactobacilli and bifidobacteria populations $(P>0.05)$ in the ileum and colon. There was a significant interaction between gastrointestinal region and $\beta$-glucan source in the expression of cytokine markers, IL-1 $\alpha(P<0 \cdot 001)$, IL-10 $(P<0 \cdot 05)$, TNF- $\alpha(P<0 \cdot 05)$ and IL-17A $(P<0 \cdot 001)$. $\beta$-Glucans did not stimulate any pro- or anti-inflammatory cytokine markers in the ileal epithelial cells. In contrast, the expression of a panel of pro- and anti-inflammatory cytokines $(I L-1 \alpha, I L-10, T N F-\alpha$ and $I L-17 A)$ was down-regulated in the colon following exposure to $\beta$-glucans from all the three sources. However, the data suggest that the soluble $\beta$-glucans derived from $L$. digitata may be acting via a different mechanism from the insoluble $\beta$-glucans derived from $L$. hyperborea and $S$. cerevisiae, as the VFA profile was different in the L. digitata-treated animals. There was an increase in $I L-8$ gene expression $(P<0.05)$ in the gastrointestinal tract from the animals exposed to L. digitata following an LPS ex vivo challenge that was not evident in the other two treatment groups. In conclusion, $\beta$-glucans from both seaweed and yeast sources reduce Enterobacteriaceae counts and pro-inflammatory markers in the colon, though the mechanisms of action may be different between the soluble and insoluble fibre sources.
\end{abstract}

Key words: Pigs: $\boldsymbol{\beta}$-Glucans: Microbiota: Pro-inflammatory cytokines

Piglets are subjected to many stresses at weaning due to a range of factors including separation from the sow, mixing with other piglets and dietary changes ${ }^{(1)}$. These abrupt changes often result in decreased feed intake and reduced daily body-weight (BW) gain. The equilibrium of the microbiota in the gut is also disrupted leading to an increased susceptibility to enteric pathogens ${ }^{(2)}$. In an attempt to control some of these problems, there has been widespread use of in-feed antibiotics at both therapeutic and sub-therapeutic levels ${ }^{(3)}$. Since the introduced ban on in-feed antibiotics, there is an urgent need to identify reliable alternatives to reduce stress-associated problems in weaned pigs.
The use of natural bioactive compounds, such as $\beta$-glucans, has received considerable attention as an alternative to infeed antibiotics ${ }^{(4-6)}$. $\beta$-Glucans are a heterogeneous group of glucose polymers, which form the main constituent of the cell walls of cereals, fungi and macroalgae. As well as being considered as a source of dietary fibre in single-stomached nutrition, $\beta$-glucans also have distinctive immunomodulatory characteristics $^{(7)}$. There is, however, considerable variation in the biochemical and solubility characteristics of $\beta$-glucans from different sources. Laminarin is a seaweed-derived $(1 \rightarrow 3)-\beta$-D-glucan with a chemical structure consisting mainly of a linear $\beta$ - $(1 \rightarrow 3)$-linked glucan with some

Abbreviations: ACTB, $\beta$-actin; BW, body weight; cDNA, complementary DNA; GAPDH, glyceraldehyde-3-phosphate dehydrogenase; LPS, lipopolysaccharide; VFA, volatile fatty acid.

*Corresponding author: J. V. O’Doherty, fax +35317161103, email john.vodoherty@ucd.ie 
random $\beta-(1 \rightarrow 6)$-linked side chains, which is dependent on the variety of seaweed ${ }^{(8)}$. $\beta$-Glucans derived from Laminaria digitata are water soluble and contain small numbers of $\beta$ - $(1 \rightarrow 6)$-linked side chains. In contrast, $\beta$-glucans derived from $L$. hyperborea are water insoluble and only contain linear $\beta$ - $(1 \rightarrow 3)$-linked residues ${ }^{(9)}$. $\beta$-Glucans derived from yeast (Saccharomyces cerevisiae) are composed mainly of branched $\beta-(1 \rightarrow 3)$-glucan (about $85 \%$ ) of high molecular weight and contain about $3 \% \beta-(1 \rightarrow 6)$-glucosidic interchain linkages ${ }^{(10)}$.

Recent studies have indicated that the inclusion of laminarin derived from Laminaria spp. in pig diets has ameliorated feed efficiency and growth performance ${ }^{(11,12)}$, and reduced Enterobacteriaceae $^{(5,6)}$. However, $\beta$-glucans vary in their structure and chemical composition which may modulate their effect on animal performance and gastrointestinal health ${ }^{(13)}$. Therefore, the first objective of the present study was to compare $\beta$-glucans derived from $L$. digitata, $L$. byperborea and $S$. cerevisiae on piglet performance, selected bacterial populations and volatile fatty acid (VFA) production. The second aim was to compare the gene expression profiles of pro- and anti-inflammatory cytokine markers in both unchallenged and lipopolysaccharide (LPS)-challenged ileal and colonic tissues.

\section{Materials and methods}

All procedures described in the present experiment were conducted under experimental licence from the Irish Department of Health in accordance with the Cruelty to Animals Act 1876 and the European Communities (Amendments of the Cruelty to Animals Act, 1876) Regulations.

\section{Experimental design and animal diets}

The present experiment was designed as a complete randomised design. A total of thirty-two, 49-d-old pigs, with an initial BW of 15.3 (SD 1.32) kg, were blocked on the basis of BW and litter of origin. The pigs had been previously weaned at $26 \mathrm{~d}$ of age. Then, the pigs were randomly assigned to one of the four dietary treatments as follows: (T1) basal diet (control, $n$ 8); (T2) basal diet supplemented with 250 parts per million (ppm) laminarin from $L$. digitata ( $n$ 8); (T3) basal diet supplemented with $250 \mathrm{ppm}$ laminarin from L. hyperborea $(n 8)$; (T4) basal diet supplemented with $250 \mathrm{ppm} \beta$-glucans from $S$. cerevisiae ( $n$ 8). Experimental feeding continued for $28 \mathrm{~d}$ ad libitum. Purified laminarin from L. digitata and L. hyperborea (990 g laminarin $/ \mathrm{kg}$ ) was sourced from Bioatlantis Limited and extracted according to the procedure described by Lynch et al. ${ }^{(14)}$. The yeast $\beta$-glucans (650 g $\beta$-glucans $/ \mathrm{kg}$ ) were sourced from Biothera. The molecular weights of the laminarin and yeast $\beta$-glucans were measured using the method of Friedlaender et $a l .{ }^{(15)}$. The molecular weights of laminarin from both varieties of seaweed were less than $5000 \mathrm{Da}$ while the molecular weights of yeast $\beta$-glucans were between 5000 and $80000 \mathrm{Da}$. $\beta$-Glucans derived from $L$. digitata were $83 \%$ water soluble while $\beta$-glucans derived from $L$. byperborea were $31 \%$ water soluble. $\beta$-Glucans derived from S. cerevisiae were $90 \%$ water insoluble. The diets were formulated to have similar digestible energy $(14.4 \mathrm{MJ} / \mathrm{kg})$ and ileal digestible lysine $(12.5 \mathrm{~g} / \mathrm{kg})$ contents The ingredient composition and chemical analysis of the dietary treatments are presented in Table 1.

\section{Animals and management}

Initially, the pigs were housed individually in fully slated pens $(1.7 \times 1.2 \mathrm{~m})$ and were allowed a $10 \mathrm{~d}$ dietary adaptation period. After that, they were weighed (18.8 (SD 1.39) kg) and transferred to individual metabolism crates which facilitated total but separate collection of urine and faeces. The pigs were given a further $5 \mathrm{~d}$ to adapt to the metabolism crates before collections begun. Nutrient faecal apparent digestibility was measured over a $5 \mathrm{~d}$ collection period. The daily food allowance (digestible energy intake in $\mathrm{MJ} / \mathrm{d}$ ) was calculated as $3.44 \times \mathrm{BW}^{0.54(16)}$ and was divided over two meals per $\mathrm{d}$. Water was provided with the meal on a $1: 1$ ratio by weight, as a mash and between meals, fresh water was provided ad libitum. The metabolism crates were located in an environmentally controlled room which was maintained at a constant temperature of $22 \pm 1.5^{\circ} \mathrm{C}$ throughout the experiment. During collections, total faeces weight was recorded daily. At the end of the collection period, faecal samples were pooled and a subsample retained for laboratory analysis. The pigs were then rehoused to their respective pens and diets until day 28 when they were humanely killed by Euthanyl injection (pentobarbitone sodium $\mathrm{BP}$ ) at a rate of $0.7 \mathrm{ml} / \mathrm{kg} \mathrm{BW}$.

Table 1. Composition and chemical analysis of the experimental diets ( $\mathrm{g} / \mathrm{kg}$, unless otherwise indicated)

\begin{tabular}{|c|c|}
\hline & Basal diet ${ }^{\star}$ \\
\hline \multicolumn{2}{|l|}{ Composition } \\
\hline Wheat & 686.7 \\
\hline Soyabean meal & $260 \cdot 0$ \\
\hline Soya oil & 24.8 \\
\hline Minerals and vitamins $\dagger$ & 23.0 \\
\hline Lysine $\mathrm{HCl}$ & 3.4 \\
\hline L-Threonine & $1 \cdot 3$ \\
\hline DL-Methionine & 0.8 \\
\hline \multicolumn{2}{|l|}{ Analysed composition } \\
\hline DM & 888.7 \\
\hline Crude protein $(\mathrm{N} \times 6.25)$ & 186.6 \\
\hline Neutral-detergent fibre & $115 \cdot 3$ \\
\hline Ash & 46.5 \\
\hline Gross energy (MJ/kg) & $17 \cdot 3$ \\
\hline Cał & 6.9 \\
\hline$P \ddagger$ & 4.4 \\
\hline Lysineł & $10 \cdot 0$ \\
\hline Methionine and cysteine $\neq$ & $6 \cdot 0$ \\
\hline Threonine & 6.5 \\
\hline Tryptophanł & $1 \cdot 8$ \\
\hline
\end{tabular}

ppm, Parts per million.

*T1, basal diet; T2, basal diet supplemented with $250 \mathrm{ppm}$ laminarin from Laminaria digitata; T3, basal diet supplemented with $250 \mathrm{ppm}$ laminarin from L. hyperborea; T4, basal diet supplemented with $250 \mathrm{ppm} \beta$-glucans from Saccharomyces cerevisiae.

† Vitamin and mineral inclusion (per $\mathrm{kg}$ diet): $3 \mathrm{mg}$ retinol; $0.05 \mathrm{mg}$ cholecalciferol; $40 \mathrm{mg} \alpha$-tocopherol; $25 \mathrm{mg} \mathrm{Cu}$ as $\mathrm{CuSO}_{4} ; 100 \mathrm{mg} \mathrm{Fe}$ as $\mathrm{FeSO}_{4} ; 100 \mathrm{mg} \mathrm{Zn}$ as $\mathrm{ZnO} ; 0.3 \mathrm{mg}$ Se as sodium selenite; $25 \mathrm{mg} \mathrm{Mn}$ as $\mathrm{MnO} ; 0.2 \mathrm{mg}$ iodine as calcium iodate on a calcium sulphate/calcium carbonate carrier.

$\ddagger$ Calculated from proximate analysis ${ }^{(39)}$. 


\section{Chemical analysis for nutrient digestibility}

Both feed and faeces were analysed for nitrogen, DM, ash, gross energy and neutral-detergent fibre. Following collection, faeces was dried at $100^{\circ} \mathrm{C}$ for $48 \mathrm{~h}$. The feed and dried faeces samples were milled through a hammer mill provided with a $1 \mathrm{~mm}$ screen (Christy and Norris). The DM of dried faeces and feed were determined after drying overnight at $103^{\circ} \mathrm{C}$. Ash was determined after ignition of a known weight of concentrates or faeces in a muffle furnace (Nabertherm) at $500^{\circ} \mathrm{C}$. The nitrogen content of both feed and faeces was determined using the LECO FP 528 instrument (Leco Instruments; UK Limited). Neutral-detergent fibre was determined using a Fibertec extraction unit (Tecator). The gross energy of the feed and faeces was determined using a Parr 1201 oxygen bomb calorimeter (Parr). The total laminarin and yeast $\beta$-glucan content in the diets was determined using a Megazyme kit (Megazyme). The solubility of both laminarin and yeast $\beta$-glucans was determined using a Megazyme kit (Megazyme).

\section{Microbial and volatile fatty acid analysis}

Immediately after slaughter, the entire digestive tract was removed by blunt dissection and the digesta (approximately 10 (SD 1) g) was removed from the ileum, $10 \mathrm{~cm}$ from the ileocaecal valve and from the second loop of the ascending colon, using sterile instruments. These digesta samples were removed and stored in sterile containers (Sarstedt) on ice and transported to the laboratory immediately. Bifidobacteria, lactobacilli and enterobacteria species were isolated according to the methods described by Pierce $e t a l{ }^{(17)}$. In brief, a $1.0 \mathrm{~g}$ sample was removed from each digesta sample, serially diluted (1:10) in $9.0 \mathrm{ml}$ aliquots of maximum recovery diluent (Oxoid), and spread plated $(0 \cdot 1 \mathrm{ml}$ aliquots) onto selective agars as follows: Lactobacillus and Bifidobacterium spp. were isolated on de Man, Rogosa, Sharp agar (Oxoid). Lactobacillus spp. were incubated overnight $(18-24 \mathrm{~h})$ at $37^{\circ} \mathrm{C}$ in a microaerophilic $\left(5 \% \mathrm{CO}_{2}\right)$ environment and bifidobacteria cultures were incubated anaerobically at $37^{\circ} \mathrm{C}$ for $72 \mathrm{~h}$ according to the manufacturer's instructions (Oxoid). An API $50 \mathrm{CHL}$ kit (BioMerieux) was used to confirm the presence of Lactobacillus spp. and a Gram stain was used to distinguish Bifidobacterium spp. from lactobacilli based on colony appearance and rod size and shape. Enterobacteriaceae species were isolated on MacConkey agar (Oxoid), following aerobic incubation at $37^{\circ} \mathrm{C}$ for $18-24 \mathrm{~h}$. Positive Enterobacteriaceae colonies were confirmed with API 20E (BioMerieux). Bacterial colonies from each plate were counted and bacterial numbers were presented as $\log _{10}$ colony-forming units/g digesta $\left(\log _{10}\right.$ colony-forming units/g digesta). Digesta samples were collected from the ileum, caecum and colon and were mixed with sodium benzoate and phenylmethylsulfonyl fluoride, in order to stop any bacterial activity and minimise the effects of post-thawing fermentation on resulting VFA concentrations. VFA analysis was performed using GLC according to the method described by Pierce et al. ${ }^{(18)}$. All $\mathrm{pH}$ measurements were made on a Mettler Toledo MP 220 pH meter. Distilled water was added to very viscous digesta samples to allow their $\mathrm{pH}$ to be read. Digesta samples from the caecum and colon were collected to determine the concentration of ammonia-nitrogen using the microdiffusion method described by Reilly et $a{ }^{(5)}$.

\section{Collection of tissue samples and tissue challenge procedure}

Ileal and colonic tissues were sampled from the same location as described for microbiological samples. Excised tissues were emptied by dissecting them along the mesentery and rinsing them using sterile PBS (Oxoid). Tissue sections of $1 \mathrm{~cm}^{2}$, which had been stripped of the overlying smooth muscle, were cut from each tissue. Then, two sections from each tissue were placed in $1 \mathrm{ml}$ of Dulbecco's modified Eagle's medium (Gibco, Invitrogen Corporation), one in the presence of bacterial LPS (Sigma Aldrich Corporation) at a concentration of $10 \mu \mathrm{g} / \mathrm{ml}$. The other tissue sample was used as a control and incubated in sterile Dulbecco's modified Eagle's medium in the absence of LPS. Both challenged and unchallenged tissues were incubated at $37^{\circ} \mathrm{C}$ for $90 \mathrm{~min}$ before being removed, blotted dry and weighed. Approximately 1000-2000 mg of the porcine ileal and colonic tissues were cut into small pieces and stored in $15 \mathrm{ml} \mathrm{RNAlater}{ }^{\circledR}$ (Applied Biosystems) overnight at $4^{\circ} \mathrm{C}$. RNAlater ${ }^{\circledR}$ was then removed before storing the samples at $-80^{\circ} \mathrm{C}$.

\section{RNA extraction and complementary DNA synthesis}

RNA was extracted from approximately $50 \mathrm{mg}$ tissue samples using the GenElute Mammalian Total RNA Minprep Kit (Sigma Aldrich Corporation) according to the manufacturer's instructions. The purity of the total RNA was analysed using $1 \mu \mathrm{l}$ of total RNA on a NanoDrop Spectrophotometer ND1000 (Thermo Scientific) and samples with a 260:280 ratio $\geq 2.0$ were considered suitable for complementary DNA (cDNA) synthesis. Total RNA integrity (i.e. quality and quantity) was also assessed by analysing $1 \mu$ l of total RNA using the Agilent 2100 Bioanalyser version A.02.12 (Agilent Technologies, Inc.) using RNA Nano LabChips ${ }^{\circledR}$ (Caliper Technologies Corporation).

cDNA synthesis was performed using $1 \mu \mathrm{g}$ of total RNA and oligo $(\mathrm{dT})_{20}$ primers in a final reaction volume of $20 \mu \mathrm{l}$ using the Superscript ${ }^{\mathrm{TM}}$ III First-Strand synthesis Kit (Invitrogen Life Technologies) following the manufacturer's instructions.

\section{Quantitative real-time $P C R$ and normalisation of quantitative $P C R$ data}

All primers for selected cytokine genes, $I L-1 \alpha, I L-4, I L-6, I L-8$, $I L-10, I L-17 A, T N F-\alpha$, interferon- $\gamma$ and toll-like receptor 4, were designed using Primer Express ${ }^{\mathrm{TM}}$ (PE Applied Biosystems) and synthesised by MWG Biotech. Primer sequences are presented in Table 2. Specificity was established in silico using BLAST and confirmed by examining the dissociation curves for each primer set. The efficiencies of all primer sets were established using a semi-log curve of quantity $v$. control, of 2-fold serial dilutions of cDNA as reported previously by 
Table 2. Porcine oligonucleotide primers used for real-time PCR

\begin{tabular}{|c|c|c|c|c|}
\hline & Forward primer $\left(5^{\prime}-3^{\prime}\right)$ & $T_{\mathrm{m}}\left({ }^{\circ} \mathrm{C}\right)$ & Reverse primer $\left(5^{\prime}-3^{\prime}\right)$ & $T_{\mathrm{m}}\left({ }^{\circ} \mathrm{C}\right)$ \\
\hline \multicolumn{5}{|l|}{ Gene name } \\
\hline$I F N-\gamma$ & TCTAACCTAAGAAAGCGGAAGAGAA & 59.7 & TTGCAGGCAGGATGACAATTA & $56 \cdot 5$ \\
\hline$I L-1 \alpha$ & CAGCCAACGGGAAGATTCTG & $59 \cdot 4$ & AATGGCTTCCAGGTCGTCAT & $57 \cdot 3$ \\
\hline IL-4 & CCAACCCTGGTCTGCTTACTG & $61 \cdot 8$ & TTGTAAGGTGATGTCGCACTTGT & 58.9 \\
\hline IL-6 & AGACAAAGCCACCACСССТAA & $59 \cdot 8$ & CTCGTTCTGTGACTGCAGCAGCTTATC & $62 \cdot 7$ \\
\hline IL-8 & CATGGACCAGAGCCAGAGAGA & $61 \cdot 8$ & GAAGGCAACAGCCAGTTTGG & $59 \cdot 4$ \\
\hline$I L-10$ & GCCTTCGGCCCAGTGAA & 57.6 & AGAGACCCGGTCAGCAACAA & 59.4 \\
\hline$T N F-\alpha$ & TGGCCCCTTGAGCATCA & $55 \cdot 2$ & CGGGCTTATCTGAGGTTTGAGA & $60 \cdot 3$ \\
\hline IL-17 & СССTGTCACTGCTGCTTCTG & 61.4 & TCATGATTCCCGCCTTCAC & $56 \cdot 7$ \\
\hline TLR4 & TGCATGGAGCTGAATTTCTACAA & $57 \cdot 1$ & GATAAATCCAGCACCTGCAGTTC & $60 \cdot 6$ \\
\hline \multicolumn{5}{|l|}{ Reference genes } \\
\hline ACTB & CAAATGCTTCTAGGCGGACTGT & $56 \cdot 0$ & TCTCATTTTCTGCGCAAGTTAGG & 61.8 \\
\hline$B M$ & CGGAAAGCCAAATTACCTGAAC & $59 \cdot 1$ & TCTCCCCGTTTTTCAGCAAAT & $59 \cdot 3$ \\
\hline Cyclophilin (HPRT) & CGGGTCCTGGCATCTTGT & 59.4 & TGGCAGTGCAAATGAAAAACTG & 58.9 \\
\hline GAPDH & CAGCAATGCCTCCTGTACCA & $60 \cdot 0$ & ACGATGCCGAAGTTGTCATG & $58 \cdot 1$ \\
\hline
\end{tabular}

$T_{\mathrm{m}}$, melting temperature; TLR4, toll-like receptor 4; ACTB, $\beta$-actin; HPRT, hypoxanthine ribose transferase cyclophilin; BM, $\beta 2$-microglobin; GAPDH, glyceraldehyde-3-phosphate dehydrogenase.

Smith et $_{\text {al }}{ }^{(6)}$. The following four porcine reference genes were used as described previously by Ryan et al. ${ }^{(19)}$ : $\beta$-actin $(A C T B)$; hypoxanthine ribose transferase cyclophilin (HPRT); glyceraldehyde-3-phosphate dehydrogenase (GAPDH); $\beta$-2-microglobulin $(B M)$. Quantitative PCR was then carried out on cDNA using the ABI PRISM 7500 Fast sequence detection system for ninety-six-well plates (Applied Biosystems). All samples were prepared in duplicate using the SYBR Green Fast PCR Master Mix (Applied Biosystems), cDNA as the template and specific primers for the genes selected. For each reaction, $5 \mu \mathrm{l}$ cDNA, $1.2 \mu \mathrm{l}$ forward and reverse primer mix $(5 \mu \mathrm{M})$ and $10 \mu$ l Fast SYBR Green PCR Master Mix (PE Applied Biosystems) were added and made up to a final volume of $20 \mu \mathrm{l}$. The two-step PCR programme was as follows: $95^{\circ} \mathrm{C}$ for $10 \mathrm{~min}$ for one cycle, followed by $95^{\circ} \mathrm{C}$ for $15 \mathrm{~s}$ and $60^{\circ} \mathrm{C}$ for $1 \mathrm{~min}$ for forty cycles.

The raw $C_{\mathrm{t}}$ values for the reference genes were converted to relative quantities using the formula $Q=E \times \Delta C_{\mathrm{t}}$, where $E$ is the PCR efficiency of the assay and $\Delta C_{\mathrm{t}}$ is the value calculated for the difference between the lowest $C_{\mathrm{t}}$ value and the $C_{\mathrm{t}}$ value of the sample in question for each gene. The relative quantities of the endogenous controls were then analysed for stability in geNorm ${ }^{(20)}$. The stability ' $M$ ' value generated by the geNorm application for the selected endogenous controls (ACTB, GAPDH and $B M$ ) which was less than 1.5 indicated their suitability as endogenous controls for these intestinal samples. The geometric mean of the relative quantities for $A C T B, G A P D H$ and $B M$ (normalisation factor) was then calculated using geNorm. The relative quantities were divided by the normalisation factor (obtained in geNorm) for that sample to give the final normalised relative expression for each target gene.

\section{Statistical analysis}

All data, except cytokine gene expression, from the experiment were analysed as a complete randomised design using the general linear model procedure of the Statistical Analysis Systems (SAS) Institute ${ }^{(21)}$. The statistical model used for cytokine gene expression data analysis included both gastrointestinal sites (ileum $v$. colon), $\beta$-glucan type and interaction between gut site and $\beta$-glucan type. Multiple regression models were used to determine the effect of VFA concentration on cytokine gene expression in the colon. Metabolic $\mathrm{BW}\left(\mathrm{BW}^{0.75}\right)$ was included as a covariate in the models. All data were checked initially for outliers and normality using the PROC Univariate procedure of the SAS Institute, version 6.11, SAS Institute ${ }^{(21)}$. The data presented in the tables are expressed as least square means with their standard errors. The probability value that denotes significance is $P<0.05$.

\section{Results and discussion}

The 2006 ban on in-feed antibiotics has prompted the search for alternative compounds, in particular bioactive materials derived from natural sources, which support animal health without inhibiting animal performance. In the present experiment, $\beta$-glucans derived from $L$. hyperborea, $L$. digitata and $S$. cerevisiae all reduced $(P<0.05)$ the Enterobacteriaceae population in the ileum and colon without influencing the lactobacilli and bifidobacteria populations. This was associated with a reduction in the expression of a number of proinflammatory genes in the colon. However, the data suggest that the soluble $\beta$-glucans from $L$. digitata may be acting via a different mechanism from the insoluble $\beta$-glucans from L. hyperborea and S. cerevisiae, as the SCFA profile (ratio of acetic:propionic acid and valeric acid) in the proximal colon was different in the $L$. digitata-treated animals, but not in the animals exposed to the $\beta$-glucans from $L$. byperborea and $S$. cerevisiae compared with the control diet. Also, there was a significant increase in $I L-8$ gene expression in the colon from the animals exposed to L. digitata following an LPS ex vivo challenge that was not evident in the L. hyperborea group.

\section{Animal performance and nutrient digestibility}

There were minimal effects on animal performance (food intake, daily gain or food conversion ratio) or digestibility 
coefficients of DM, organic matter, ash, nitrogen or gross energy, with $\beta$-glucan inclusion from either the seaweed or yeast sources $(P>0 \cdot 05$; results not shown). The fact that purified $\beta$-glucans, from both macroalgal sources and yeast, did not influence performance measurements is important as any natural alternative feed supplement in the porcine diet should not compromise the host in any way. In contrast, previous studies have reported a decrease in average daily gain in pigs supplemented with extracts of Ascophyllum nodosum ${ }^{(22)}$. However, this extract also contained phenolic compounds and alginates. Hence, the extraction and purification methodologies can have a substantial effect on the biological properties of these compounds.

\section{Microbiology and volatile fatty acids}

There was a significant reduction $(P<0.05)$ in Enterobacteriaceae in the ileum and colon with $\beta$-glucans derived from $S$. cerevisiae, L. hyperborea and L. digitata (Table 3). The relevance of measuring Enterobacteriaceae populations as an indicator of pathogenic bacteria is debated. However, increased coliform counts were recorded in the intestine of scouring pigs ${ }^{(23)}$ and the density of coliforms in the gastrointestinal tract is used as an indicator of salmonella and Escherichia coli in pigs ${ }^{(24,25)}$. Hence, coliform reductions due to dietary intervention are, within limits, considered by many to be beneficial ${ }^{(22,24)}$.

Bifidobacteria and lactobacilli populations were enumerated as a reflection of changes in the population structure of beneficial bacteria ${ }^{(26)}$. There was no effect of $\beta$-glucans on the number of bifidobacteria or lactobacilli in the ileum, caecum or colon in the present experiment. This is consistent with previously published work in pigs offered laminarin from $L$. digitata ${ }^{(6)}$.

The amount and composition of the resident microbiota and fermentable substrate affect the quantity and composition of VFA produced in the large intestine ${ }^{(27)}$. Seaweed-derived polysaccharides are considered to be a source of dietary fibre, as they are resistant to hydrolysis by digestive enzymes in the upper gastrointestinal tract ${ }^{(28)}$, which explains the low concentration of VFA in the ileum of supplemented pigs (Table 4). There was a significant decrease in total VFA concentrations in the ileum with the inclusion of laminarin from L. byperborea compared with the control diet (Table 4). $\beta$-D-Glucans from $L$. hyperborea do not have a high degree of branching, making them predominately insoluble in water, and, as a result, escape hydrolysis in the upper gastrointestinal tract.

There was an increase $(P<0.05)$ in the molar proportion of acetic acid and a decrease in the molar proportion of propionic acid $(P<0.05)$ in the ileum with the inclusion of laminarin from $L$. digitata compared with the control. There was an increase $(P<0.05)$ in total VFA in the caecum with the inclusion of laminarin from $L$. digitata and $S$. cerevisiae compared with the control diet. There was also a decrease $(P<0.05)$ in the molar proportion of acetic acid in the colon with the inclusion of laminarin from $L$. digitata compared with the control and $L$. byperborea diets. The ratio of acetic: propionic acid was lower $(P<0.05)$ in the colon with the inclusion of laminarin from $L$. digitata compared with all the other diets. Previous research has reported that the ratio of acetic:propionic acid decreases when carbohydrate replaces protein as the fermentation substrate ${ }^{(29)}$. This is due to a low digesta $\mathrm{C}: \mathrm{N}$ ratio in the large intestine, possibly from a lack of specific carbohydrate. In the present experiment, the $\mathrm{NH}_{3}$ concentration in the colon was lower $(P<0.05)$ with the inclusion of laminarin from $L$. digitata compared with the control diet. The decrease in the acetic:propionic acid ratio as well as a decrease in $\mathrm{NH}_{3}$ concentration in the colon due to laminarin supplementation from $L$. digitata indicates that this source of laminarin is being fermented in the colon.

\section{Cytokine gene expression}

The expression of cytokine markers, IL-6 $(P<0.05)$ and IL-8 $(P<0.01)$, was lower in the ileum than in the colon of pigs. There was a significant interaction between gastrointestinal region and $\beta$-glucan source in the expression of the cytokine markers IL-1 $\alpha(P<0 \cdot 001)$, IL-10 $(P<0 \cdot 05)$, TNF- $\alpha(P<0 \cdot 05)$ and IL-17A $(P<0 \cdot 001)$. $\beta$-Glucans did not stimulate any

Table 3. Effect of seaweed- and yeast-derived $\beta$-glucans on selected microbial populations in the ileum, caecum and colon of pigs (log ${ }_{10}$ colony-forming units/g digesta)

(Least-square mean values and standard errors, $n 8$ pigs per treatment)

\begin{tabular}{|c|c|c|c|c|c|c|}
\hline Treatment & Control & Laminaria digitata & Laminaria hyperborea & Saccharomyces cerevisiae & SE & Significance \\
\hline \multicolumn{7}{|l|}{ Ileum } \\
\hline Bifidobacteria spp. & 5.94 & 4.84 & 5.90 & $5 \cdot 39$ & 0.523 & NS \\
\hline Enterobacteria spp. & $3.45^{\mathrm{a}}$ & $1.57^{\mathrm{b}}$ & $1.52^{\mathrm{b}}$ & $1.07^{\mathrm{b}}$ & 0.701 & 0.035 \\
\hline Lactobacilli spp. & $5 \cdot 81$ & 4.96 & 5.98 & $5 \cdot 12$ & 0.579 & NS \\
\hline \multicolumn{7}{|l|}{ Caecum } \\
\hline Bifidobacteria spp. & $6 \cdot 39$ & $6 \cdot 35$ & $6 \cdot 70$ & $6 \cdot 81$ & 0.281 & NS \\
\hline Enterobacteria spp. & $3 \cdot 10$ & $2 \cdot 81$ & 2.98 & 1.86 & 0.570 & NS \\
\hline Lactobacilli spp. & $6 \cdot 29$ & 6.78 & $6 \cdot 76$ & $7 \cdot 83$ & 0.345 & NS \\
\hline \multicolumn{7}{|l|}{ Proximal colon } \\
\hline Bifidobacteria spp. & 6.75 & 6.33 & 6.84 & 6.75 & 0.270 & NS \\
\hline Enterobacteria spp. & $5 \cdot 20^{\mathrm{a}}$ & $3.23^{b}$ & $2 \cdot 21^{\mathrm{b}}$ & $2 \cdot 70^{\mathrm{b}}$ & 0.612 & 0.037 \\
\hline Lactobacilli spp. & $7 \cdot 11$ & $6 \cdot 67$ & $7 \cdot 15$ & $7 \cdot 18$ & 0.329 & NS \\
\hline
\end{tabular}

${ }^{\mathrm{a}, \mathrm{b}}$ Least-square mean values within a row with unlike superscript letters were significantly different $(P<0.05)$. 
Table 4. Effect of seaweed- and yeast-derived $\beta$-glucans on the total volatile fatty acid (VFA; mmol/l wet digesta) concentrations, the molar proportions of VFA, and $\mathrm{pH}$ in the ileum, caecum, and proximal colon

(Least-square means values and standard errors, $n 8$ pigs per treatment)

\begin{tabular}{|c|c|c|c|c|c|c|}
\hline Treatment & Control & Laminaria digitata & Laminaria hyperborea & Saccharomyces cerevisiae & SE & Significance \\
\hline \multicolumn{7}{|l|}{ lleum } \\
\hline Total VFA & $35 \cdot 5^{\mathrm{b}}$ & $30 \cdot 8^{a, b}$ & $21.9^{\mathrm{a}}$ & $27 \cdot 4^{\mathrm{a}, \mathrm{b}}$ & 4.75 & 0.0299 \\
\hline Acetic acid & $0.843^{a}$ & $0.911^{b}$ & $0.890^{a, b}$ & $0.895^{a, b}$ & 0.024 & 0.0345 \\
\hline Propionic acid & $0.047^{\mathrm{a}}$ & $0.025^{\mathrm{b}}$ & $0.037^{a, b}$ & $0.029^{a, b}$ & 0.007 & 0.0412 \\
\hline Isobutyric acid & 0.005 & 0.005 & 0.006 & 0.005 & 0.002 & NS \\
\hline Butyric acid & 0.045 & 0.034 & 0.043 & 0.036 & 0.009 & NS \\
\hline Isovaleric acid & 0.006 & 0.011 & 0.010 & 0.009 & 0.003 & NS \\
\hline Valeric acid & 0.009 & 0.013 & 0.014 & 0.018 & 0.005 & NS \\
\hline Acetic:propionic acid ratio & $20 \cdot 7$ & $37 \cdot 0$ & $30 \cdot 8$ & 28.2 & $6 \cdot 62$ & NS \\
\hline Branched-chain fatty acids & 0.044 & 0.029 & 0.030 & 0.033 & 0.013 & NS \\
\hline $\mathrm{pH}$ & 6.773 & 6.920 & 6.916 & 6.440 & 0.177 & NS \\
\hline \multicolumn{7}{|l|}{ Caecum } \\
\hline Total VFA & $147 \cdot 9^{\mathrm{a}}$ & $161 \cdot 8^{\mathrm{b}}$ & $155 \cdot 3^{a, b}$ & $164 \cdot 5^{\mathrm{b}}$ & 4.69 & 0.0345 \\
\hline Acetic acid & 0.587 & 0.584 & 0.600 & 0.584 & 0.010 & NS \\
\hline Propionic acid & 0.288 & 0.292 & 0.278 & 0.291 & 0.009 & NS \\
\hline Isobutyric acid & 0.002 & 0.002 & 0.002 & 0.002 & 0.001 & NS \\
\hline Butryic acid & 0.109 & 0.100 & 0.104 & $0 \cdot 107$ & 0.006 & NS \\
\hline Isovaleric acid & 0.002 & 0.002 & 0.002 & 0.002 & 0.001 & NS \\
\hline Valeric acid & 0.013 & 0.015 & 0.014 & 0.015 & 0.001 & NS \\
\hline Acetic:propionic acid ratio & 2.07 & 2.02 & $2 \cdot 18$ & $2 \cdot 01$ & 0.096 & NS \\
\hline Branched-chain fatty acids & 0.017 & 0.024 & 0.017 & 0.018 & 0.003 & NS \\
\hline $\mathrm{pH}$ & $5 \cdot 523$ & $5 \cdot 506$ & 5.583 & 5.483 & 0.061 & NS \\
\hline \multicolumn{7}{|l|}{ Proximal colon } \\
\hline Total VFA & $159 \cdot 4$ & $164 \cdot 1$ & $164 \cdot 6$ & $160 \cdot 9$ & 4.26 & NS \\
\hline Acetic acid & $0.592^{b}$ & $0.563^{a}$ & $0.592^{b}$ & $0.585^{\mathrm{a}, \mathrm{b}}$ & 0.010 & 0.0398 \\
\hline Propionic acid & 0.275 & 0.291 & 0.280 & 0.281 & 0.008 & NS \\
\hline Isobutyric acid & 0.003 & 0.003 & 0.002 & 0.002 & 0.001 & NS \\
\hline Butryic acid & 0.111 & 0.110 & $0 \cdot 107$ & 0.109 & 0.006 & NS \\
\hline Isovaleric acid & 0.004 & 0.003 & 0.003 & 0.003 & 0.001 & NS \\
\hline Valeric acid & $0.015^{a}$ & $0.022^{b}$ & $0.016^{a}$ & $0.017^{\mathrm{a}}$ & 0.001 & 0.0486 \\
\hline Acetic:propionic acid ratio & $2 \cdot 185^{\mathrm{b}}$ & $1.903^{\mathrm{a}}$ & $2 \cdot 133^{\mathrm{b}}$ & $2 \cdot 091^{\mathrm{b}}$ & 0.095 & 0.0452 \\
\hline Branched-chain fatty acids & 0.022 & 0.027 & 0.022 & 0.025 & 0.003 & NS \\
\hline $\mathrm{pH}$ & $5 \cdot 780$ & $5 \cdot 675$ & $5 \cdot 656$ & 5.693 & 0.093 & NS \\
\hline \multicolumn{7}{|l|}{$\mathrm{NH}_{3}$ concentration $(\mathrm{mg} / \mathrm{l})$} \\
\hline Caecum & $13 \cdot 2$ & 9.9 & $14 \cdot 2$ & $11 \cdot 2$ & $2 \cdot 35$ & NS \\
\hline Colon & $43 \cdot 3^{\mathrm{b}}$ & $20 \cdot 7^{\mathrm{a}}$ & $29 \cdot 7^{a, b}$ & $31 \cdot 3^{a, b}$ & 4.83 & 0.0483 \\
\hline
\end{tabular}

${ }^{a, b}$ Least-square mean values within a row with unlike superscript letters were significantly different $(P<0.05)$.

pro- or anti-inflammatory cytokine markers in the ileal epithelial cells. In contrast, the expression of a panel of proand anti-inflammatory cytokines $(I L-1 \alpha, T N F-\alpha, I L-10$ and $I L-$ $17 A$ ) was down-regulated in the colon following exposure to $\beta$-glucans from all the three sources (Table 5 ). The panel of the cytokines down-regulated ( $I L-1 \alpha, I L-10, T N F-\alpha$ and $I L-17 A)$ in the colon with the inclusion of $\beta$-glucans is extremely interesting, as they are all up-regulated in inflammatory bowel conditions such as ulcerative colitis and Crohn's disease $^{(30)}$. Seaweed-derived polysaccharides are resistant to hydrolysis by digestive enzymes in the upper gastrointestinal tract ${ }^{(28)}$, which may explain the lower expression of the cytokine markers in the ileum compared with the colon of supplemented pigs. A wide variety of studies have clearly demonstrated that the diet affects the gut microbiota and that the composition and metabolites of the gut microbiota can have distinctive effects on immune and inflammatory responses in the gut. A specific subset of the gut microbiota influences T-cell differentiation in the lamina propria where the $I L-17$-expressing T-cell subset is particularly abundant ${ }^{(31)}$.

In the present experiment, animals exposed to $L$. digitata had a decrease $(P<0.05)$ in Enterobacteriaceae numbers in the colon and a concomitant change in total VFA concentrations in the caecum and the VFA profile in the colon, characterised by a decreased acetic:propionic acid ratio. This strongly supports the hypothesis of Maslowski \& Mackay ${ }^{(32)}$ who hypothesised that SCFA bind to the GPR43 receptor, which causes the down-regulation of pro-inflammatory cytokines. Hence, we hypothesise that the increased soluble fibre from the $L$. digitata supplementation altered the colon microbiota resulting in an altered SCFA profile in the colon, which causes the down-regulation of the pro-inflammatory cytokines measured in the colon in the present experiment. In the present study, there was a positive relationship between acetic acid concentration and IL- $1 \alpha$ expression $\left(R^{2} 0.84\right.$, $P<0.05)$ in the colon. There was also a positive relationship between acetic acid concentration and IL-10 expression $\left(R^{2} 0.83, P<0.05\right)$ in the colon. It is proposed that laminarin from $L$. digitata inhibits either the production of protein fermentative end products or the bacterial populations responsible for producing them. Previous research has reported that the ratio of acetic:propionic acid decreases when carbohydrate replaces protein as the fermentation substrate ${ }^{(29)}$. Such fermentation can lead to the formation of toxic 
Table 5. Effect of seaweed- and yeast-derived $\beta$-glucans and gastrointestinal (GI) site on the immune response following an ex vivo lipopolysaccharide (LPS) tissue challenge (Least-square means of fold change of normalised relative gene expression and standard errors, $n 8$ pigs per treatment)

\begin{tabular}{|c|c|c|c|c|c|c|c|c|c|c|c|c|}
\hline \multirow[b]{3}{*}{$\mathrm{T} \ldots$} & \multicolumn{8}{|c|}{ GI region } & \multirow[b]{3}{*}{ SE } & \multirow{2}{*}{\multicolumn{3}{|c|}{ Significance }} \\
\hline & \multicolumn{4}{|c|}{ Ileum } & \multicolumn{4}{|c|}{ Colon } & & & & \\
\hline & Control & L. digitata & L. hyperborea & S. cerevisiae & Control & L. digitata & L. hyperborea & S. cerevisiae & & $\mathrm{T}$ & Gl & $\mathrm{T} \times \mathrm{Gl}$ \\
\hline \multicolumn{13}{|l|}{ PBS } \\
\hline IL-4 & 0.0397 & 0.0984 & 0.1357 & 0.1262 & 0.1402 & $0 \cdot 117$ & 0.0160 & 0.0084 & 0.0426 & 0.8932 & 0.0957 & 0.0732 \\
\hline IL-6 & 0.0084 & 0.0098 & 0.0078 & 0.1474 & 0.4516 & 0.1575 & 0.1498 & 0.1633 & 0.1059 & 0.4398 & 0.0143 & 0.2282 \\
\hline IL-8 & 0.1765 & 0.0931 & 0.1027 & 0.1080 & 0.2939 & 0.2215 & 0.2394 & 0.2461 & 0.0668 & 0.6789 & 0.008 & 0.9986 \\
\hline IL-10 & 0.0336 & 0.0389 & 0.0515 & 0.0322 & 0.3483 & 0.1652 & 0.2627 & 0.1917 & 0.0327 & 0.0356 & 0.0001 & 0.0384 \\
\hline TNF- $\alpha$ & 0.1593 & 0.2113 & 0.1872 & 0.1520 & 0.5138 & 0.2352 & 0.1603 & 0.1250 & 0.0896 & 0.1599 & 0.2043 & 0.0499 \\
\hline IL-17A & 0.0589 & 0.0931 & 0.0627 & 0.1028 & 0.4477 & 0.0525 & 0.1301 & 0.1047 & 0.0512 & 0.0062 & 0.0062 & 0.0008 \\
\hline IFN- $\gamma$ & 0.1033 & 0.1104 & 0.1082 & 0.1370 & 0.1487 & 0.1236 & 0.1525 & 0.1851 & 0.031 & 0.5141 & 0.0961 & 0.9345 \\
\hline IL-1 $1 \alpha$ & 0.1163 & 0.0998 & 0.0955 & 0.0886 & 0.5205 & 0.1613 & 0.1943 & 0.1635 & 0.0483 & 0.0005 & 0.0001 & 0.0025 \\
\hline TLR4 & 0.1607 & 0.1229 & 0.1090 & 0.0862 & 0.1200 & 0.2162 & 0.0953 & 0.1912 & 0.0563 & 0.6484 & 0.3329 & 0.3893 \\
\hline \multicolumn{13}{|l|}{ LPS } \\
\hline IL-4 & 0.004 & 0.0845 & 0.1680 & 0.0925 & 0.1185 & 0.1285 & 0.0085 & 0.0120 & 0.4853 & 0.7529 & 0.0786 & 0.1933 \\
\hline IL-6 & 0.0060 & 0.0098 & 0.0137 & 0.1385 & 0.2514 & 0.2142 & 0.2357 & 0.1000 & 0.0810 & 0.9973 & 0.0089 & 0.2868 \\
\hline IL-8 & 0.0911 & 0.1229 & 0.0942 & 0.0421 & 0.1385 & 0.4342 & 0.1385 & 0.2400 & 0.0661 & 0.0492 & 0.0027 & 0.1472 \\
\hline IL-10 & 0.0427 & 0.0430 & 0.0476 & 0.0575 & 0.2785 & 0.2957 & 0.2357 & 0.1566 & 0.0368 & 0.3503 & 0.0001 & 0.1710 \\
\hline TNF- $\alpha$ & 0.2215 & 0.1742 & 0.2164 & 0.1321 & 0.1628 & 0.2271 & 0.1557 & 0.1366 & 0.0370 & 0.2933 & 0.5617 & 0.3695 \\
\hline IL-17A & 0.0349 & 0.1151 & 0.1612 & 0.0677 & 0.1840 & 0.0828 & 0.1571 & 0.0566 & 0.0382 & 0.1264 & 0.1877 & 0.1410 \\
\hline IFN- $\gamma$ & 0.0525 & 0.1062 & 0.1224 & 0.1063 & 0.0914 & 0.0957 & 0.1300 & 0.1150 & 0.0311 & 0.3903 & 0.6194 & 0.8914 \\
\hline IL-1 $1 \alpha$ & 0.0854 & 0.0940 & 0.1201 & 0.0723 & 0.1833 & 0.2157 & 0.1314 & 0.1383 & 0.0334 & 0.5313 & 0.0031 & 0.3939 \\
\hline TLR4 & 0.0842 & 0.1228 & 0.0922 & 0.1127 & 0.1133 & 0.1400 & 0.1400 & 0.0850 & 0.0373 & 0.7596 & 0.5078 & 0.7362 \\
\hline
\end{tabular}

T, treatment; L., Laminaria, S., Saccharomyces; IFN- $\gamma$, interferon- $\gamma$; TLR4, toll-like receptor 4. 
metabolites such as $\mathrm{NH}_{3}$ and amines ${ }^{(33)}$, as has been shown in the present experiment, that have been implicated in the clinical expression of diarrhoea ${ }^{(34)}$. Second, there may be a possibility of an interaction between laminarin from $L$. digitata and fibre coming from the other ingredients. However, it was not within the scope of the present experiment to test this theory

In contrast, the mechanism by which L. hyperborea and $S$. cerevisiae suppress pro-inflammatory cytokines appears to be different from that of $L$. digitata. This could be expected, as the physical characteristics of $\beta$-glucans from both sources of macroalgae are different: $L$. digitata is a soluble fibre, while both $L$. byperborea and yeast are insoluble fibres ${ }^{(9,10)}$. While supplementation with $L$. byperborea has resulted in a reduction in Enterobacteriaceae counts in the colon as well as a suppression of pro-inflammatory cytokines, there is no modification in the VFA profiles. A similar effect of L. byperborea on Enterobacteriaceae and VFA has previously been reported ${ }^{(14)}$. Hence, the mode of action of $L$. byperborea is most probably SCFA/GPR43R independent.

It is possible that the insoluble nature of these extracts acts as anti-adhesive or coagulative agents, suppressing the ability for a subpopulation of Enterobacteriaceae from adhering to the gastrointestinal epithelium or causing them to agglutinate and be excreted in the faeces. Unlike carrageenan ${ }^{(35)}, \beta$-D-glucans used in the present experiment had no effect on the expression of toll-like receptor 4. Further research is warranted to explore the receptors that interact with $\beta$-D-glucans and the intracellular signalling systems activated downstream

\section{Cytokine gene expression in response to an lipopolysaccharide challenge}

To mimic the response of the ileal and colonic tissues of animals exposed to $\beta$-glucans to a microbial challenge, these tissues were subsequently incubated with LPS ex vivo. The expression of the cytokine markers IL-1 $\alpha$ ( $P<0 \cdot 01)$, IL-6 $(P<0 \cdot 01)$, IL- $8(P<0 \cdot 01)$ and IL-10 $(P<0 \cdot 001)$ was lower in the ileum than in the colon of pigs. There was an effect observed $(P<0.05)$ for $I L-8$ gene expression of LPS-challenged tissues in animals exposed to $L$. digitata (Table 5 ). These data suggest that inclusion of laminarin from $L$. digitata in the diet could enhance the pro-inflammatory response to a microbial challenge - as far as can be extrapolated from an LPS challenge. The potential benefit of this enhanced gene upregulation of $I L-8$ cytokines following the LPS challenge is significant for the host as the chemokine $I L-8$ plays an important role in acute inflammation and is responsible for neutrophil recruitment and activation to the initial site of infection ${ }^{(36)}$. A similar effect of $L$. digitata-derived $\beta$-glucan on $I L-8$ has previously been observed in this model ${ }^{(6)}$. This effect was not seen in animals exposed to $\beta$-glucan from $L$. byperborea or S. cerevisiae.

It is noteworthy that the level of inclusion of $\beta$-glucans used in the present experiment is very low (250 ppm) compared with the levels required for cereal $\beta$-glucans $(20-40 \mathrm{~g} / \mathrm{kg})^{(37)}$ in order to show a biological response. $\beta$-Glucans derived from cereals are polysaccharides of glucose residues with $\beta$-(1 $\rightarrow 3), \beta$ - $(1 \rightarrow 4)$ linkages with high molecular weights ${ }^{(38)}$ The biological activity that $\beta$-glucans exhibit depends on parameters such as primary structure, solubility, degree of branching and molecular weight, as well as the charge of their polymers and structure in aqueous media. In the present experiment, $\beta$-glucans were incorporated into the experimental diets on a weight basis. This could have a confounding effect on $\beta$-glucans derived from $S$. cerevisiae since these $\beta$-glucans had a higher molecular weight than those derived from $L$. byperborea and $L$. digitata. Therefore, there may be a justification for including $\beta$-glucans in a diet on a molar basis rather than on a weight basis. However, previous work has shown that the optimum inclusion rate for $\beta$-glucans derived from $S$. cerevisiae is the range used for the present experiment $(150-250 \mathrm{ppm})^{(13)}$.

\section{Conclusion}

$\beta$-Glucans derived from $L$. byperborea, L. digitata and $S$. cerevisiae all reduced the Enterobacteriaceae population in the ileum and colon without influencing the lactobacilli and bifidobacteria populations. This was associated with a reduction in the expression of a number of pro-inflammatory cytokine genes in the colon. However, the data suggest that the soluble $\beta$-glucans from $L$. digitata may be acting via a different mechanism than the insoluble $\beta$ glucans from $L$. byperborea and $S$. cerevisiae. There was a significant increase in $I L-8$ gene expression in the tissues from animals exposed to L. digitata following an LPS ex vivo challenge that was not evident in the L. byperborea- or $S$. cerevisiaesupplemented diets.

\section{Acknowledgements}

Funding for this study was provided under the National Development Plan, through the FIRM Fund, administered by the Department of Agriculture, Fisheries and Food, Ireland. The contributions of each author are as follows: T. S. wrote the manuscript and designed the study with J. V. O. D.; J. V. O. D. designed the study, analysed the data and participated in writing and correcting the manuscript; P. R. and K. M. P. fed the pigs, collected the samples and carried out the laboratory analysis; C. B. C. and M. R. extracted the RNA and carried out the real-time PCR; K. M. P. designed the study and participated in writing and correcting the manuscript. None of the authors had any conflict of interest.

\section{References}

1. Pluske JR, Hampson DJ \& Williams IH (1997) Factors influencing the structure and function of the small intestine in the weaned pig. Livest Prod Sci 51, 215-236.

2. Hampson DJ (1986) Attempts to modify changes in the piglet small intestine after weaning. Res Vet Sci 40, 313-317.

3. Williams BA, Verstegen MWA \& Tamminga S (2001) Fermentation in the large intestine of single stomached animals and its relationship to human health. Nut Res Rev 14, 207-227.

4. Hahn TW, Lohakare JD, Lee SL, et al. (2006) Effects of supplementation of $\beta$-glucans on growth performance, nutrient 
digestibility, and immunity in weanling pigs. J Anim Sci 84 , $1422-1428$.

5. Reilly P, O'Doherty JV, Pierce KM, et al. (2011) The effects of seaweed extract inclusion on gut morphology, selected intestinal microbiota, nutrient digestibility, volatile fatty acid concentrations and the immune status of the weaned pig. Animal 2, 1465-1473.

6. Smith AG, O'Doherty JV, Reilly P, et al. (2011) The effects of laminarin derived from Laminaria digitata on measurements of gut health: selected bacterial populations, intestinal fermentation, mucin gene expression and cytokine gene expression in the pig. Br J Nutr 105, 669-677.

7. MacArtain P, Gill CIR, Brooks M, et al. (2007) Nutritional value of edible seaweeds. Nutr Rev 65, 535-543.

8. Brown GD \& Gordon S (2005) Immune recognition of fungal $\beta$-glucans. Cell Microbiol 7, 471-479.

9. Read SM, Currie G \& Bacic A (1996) Analysis of the structural heterogeneity of laminarian by electrospray-ionisation-mass spectrometry. Carbohydr Res 281, 187-201.

10. Manners DJ, Masson AJ \& Patterson JC (1973) The structure of a $\beta$-( $1 \rightarrow 3)$-D-glucan from yeast cell walls. Biochem J 135 , 19-30.

11. Gahan DA, Lynch MB, Callan JJ, et al. (2009) Performance of weanling piglets offered low-, medium- or high-lactose diets supplemented with a seaweed extract from Laminaria spp. Animal 3, 24-31.

12. McDonnell P, Figat S \& O'Doherty JV (2010) The effect of dietary laminarin and fucoidan in the diet of the weanling piglet on performance, selected faecal microbial populations and volatile fatty acid concentrations. Animal 4, 579-585.

13. Li J, Li DF, Xing JJ, et al. (2006) Effects of $\beta$-glucan extracted from Saccharomyces cerevisiae on growth performance, and immunological and somatotropic responses of pigs challenged with Escherichia coli lipopolysaccharide. J Anim Sci 84, 2374-2381.

14. Lynch MB, Sweeney T, Callan JJ, et al. (2010) The effect of dietary Laminaria-derived laminarin and fucoidan on nutrient digestibility, nitrogen utilisation, intestinal microflora and volatile fatty acid concentration in pigs. J Sci Food Agric $\mathbf{9 0}$, 430-437.

15. Friedlaender MHG, Cook WH \& Martin WG (1954) Molecular weight and hydrodynamic properties of laminarin. Biochim Biophys Acta 14, 136-144.

16. Close WH (1994) Feeding new genotypes: establishing amino acid/energy requirements. In Principles of Pig Science, pp. 123-140 [DJA Cole, J Wiseman and MA Varley, editors]. Loughborough: Nottingham University Press.

17. Pierce KM, Sweeney T, Brophy PO, et al. (2005) Dietary manipulation post weaning to improve piglet performance and gastro-intestinal health. Anim Sci 81, 347-356.

18. Pierce KM, Sweeney T, Brophy PO, et al. (2006) The effect of lactose and inulin on intestinal morphology, selected microbial populations and volatile fatty acid concentrations in the gastro-intestinal tract of the weanling pig. Anim Sci 82, $311-318$.

19. Ryan MT, Collins CB, O'Doherty JV, et al. (2010) Selection of stable reference genes for quantitative real-time PCR in porcine gastrointestinal tissues. Livest Sci 133, 42-44.

20. Vandesompele J, De Preter K, Pattyn F, et al. (2002) Accurate normalization of real-time quantitative RT-PCR data by geometric averaging of multiple internal control genes. Genome Biol 3, research 0034.1-0034.11.

21. Statistical Analysis Systems Institute (1985) Statistical Analysis Systems, version 6.12. Cary, NC: SAS Institute, Inc.
22. Gardiner GE, Campbell AJ, O'Doherty JV, et al. (2008) Effect of Ascophyllum nodosum extract on growth performance, digestibility, carcass characteristics and selected intestinal microflora populations of grower-finisher pigs. Anim Feed Sci Technol 141, 259-273.

23. Muralidhara KS, Sheggeby GG, Elliker PR, et al. (1977) Effect of feeding lactobacilli on the coliform and Lactobacillus flora of intestinal tissue and feces from piglets. J Food Prot $\mathbf{4 0}$, $288-295$.

24. Jørgensen L, Hansen CF \& Kjærsgaard H, et al. (2002) Particle Size in Meal Feed to Slaughter Pigs. Effects on Productivity, Salmonella prevalence, and the Gastrointestinal Ecosystem Publication No. 580. The National Commitee for Pig Production, Copenhagen, Denmark

25. Mikkelsen LL, Naughton PJ, Hedemann MS, et al. (2004) Effects of physical properties of feed on microbial ecology and survival of Salmonella enterica serovar Typhimurium in the pig gastrointestinal tract. Appl Environ Microbiol 70, 3485-3492.

26. Leser TD, Amenuvor JZ, Jensen TK, et al. (2002) Cultureindependent analysis of gut bacteria: the pig gastrointestinal tract microbiota revisited. Appl Environ Microbiol 68 , 673-690.

27. Macfarlane S \& Macfarlane GT (2003) Regulation of shortchain fatty acid production. Proc Nutr Soc 62, 67-72.

28. Deville C, Damas J, Forget P, et al. (2004) Laminarin in the dietary fibre concept. J Sci Food Agric 84, 1030-1038.

29. Marounek M, Adamec T, Skrivanová V, et al. (2002) Nitrogen and in vitro fermentation of nitrogenous substrates in caecal contents of the pig. Acta Vet Brno 71, 429-433.

30. Ahern PP, Izcue A, Maloy KJ, et al. (2008) The interleukin-23 axis in intestinal inflammation. Immunol Rev 226, 147-159.

31. Ivanov Frutos II, Rde L, Manel N, et al. (2008) Specific microbiota direct the differentiation of IL-17-producing T-helper cells in the mucosa of the small intestine. Cell Host Microbe 4, 337-349.

32. Maslowski KM \& Mackay CR (2011) Diet, gut microbiota and immune responses. Nat Immunol 12, 5-9.

33. Russell JB, Sniffen CJ \& Van Soest PJ (1983) Effect of carbohydrate limitation on degradation and utilization of casein by mixed rumen bacteria. J Dairy Sci 66, 763-775.

34. Aumaitre A, Peiniau J \& Madec F (1995) Digestive adaptation after weaning and nutritional consequences in the piglet. Pig News Inf 16, 73N-79N.

35. Bhattacharyya S, Gill R, Chen ML, et al. (2008) Toll-like receptor 4 mediates induction of the Bc110-NFkB-interleukin-8 inflammatory pathway by carrageenan in human intestinal epithelial cells. J Biol Chem 283, 10550-10558.

36. Barton B (1996) The biological effects of interleukin 6. Med Res Rev 16, 87-109.

37. Reilly P, Sweeney T, O'Shea C, et al. (2010) The effect of cereal-derived beta-glucans and exogenous enzyme supplementation on intestinal microflora, nutrient digestibility, mineral metabolism and volatile fatty acid concentrations in finisher pigs. Anim Food Sci Technol 158, 165-176.

38. Brennan CS \& Cleary LJ (2005) The potential use of cereal $(1-3,1-4)-\beta-D-g l u c a n s$ as functional food ingredients. J Cereal Sci 42, 1-13.

39. Sauvant D, Perez JM \& Tran G (2004) Tables of Composition and Nutritional Value of Feed Materials: Pigs, Poultry, Cattle, Sheep, Goats, Rabbits, Horses, Fish. Wageningen, Netherlands and INRA Versailles: Wageningen Academic Publishers. 